\title{
The effect of glutamine on oxidative damage in an experimental abdominal compartment syndrome model in rats
}

\author{
Siçanlarda oluşturulan deneysel abdominal kompartman sendromunda \\ glutaminin oksidatif hasar üzerindeki etkileri
}

\author{
Deniz Necdet TİHAN, ${ }^{1}$ Yeşim ERBİL, ${ }^{1}$ Rıdvan SEVEN, ${ }^{1}$ Selda ARKAYA, ${ }^{2}$ \\ Ümit TÜRKOĞLU, ${ }^{2}$ Gülçin HEPGÜL, ${ }^{3}$ İsmail BORUCU ${ }^{1}$
}

\section{BACKGROUND}

The aim was to investigate whether or not glutamine, an antioxidant effective amino acid, improves the reperfusioninduced oxidative injury of abdominal hypertension.

\section{METHODS}

Wistar Albino rats were used. Group 1: Abdominal compartment syndrome alone: With the rats under anesthesia, intraabdominal pressure was obtained. Three days later, the rats were sacrificed, and intestine, lung and liver samples were removed for determination of tissue malondialdehyde (MDA) and glutathione (GSH) levels as oxidative injury parameters and of myeloperoxidase (MPO) activity as an inflammatory parameter. Trunk blood was analyzed for the alanine aminotransferase (ALT) and aspartate aminotransferase (AST) levels. Group 2: Abdominal compartment syndrome and glutamine: intragastric glutamine was given for seven days before and three days following establishment of the abdominal compartment syndrome model. The same examination procedure was then performed. Group 3: Glutamine administration alone. Group 4: Control group.

\section{RESULTS}

Intraabdominal pressure significantly increased the intestine, lung and liver MDA levels and MPO activities in comparison to the control group. Glutamine was associated with decreased MDA levels and MPO activities and increased GSH levels.

\section{CONCLUSION}

Glutamine appears to have protective effects against reperfusion-induced oxidative damage via its anti-inflammatory and antioxidant effect.

Key Words: Abdominal compartment syndrome; antioxidant; glutamine; glutathione; ischemia; malondialdehyde; myeloperoxidase; oxidative stress; reperfusion.

\section{AMAÇ}

Bu çalışmada, antioksidan özelliği bilinen glutaminin kullanımının iskemi-reperfüzyon sonrası oluşabilecek oksidasyon hasarı üzerindeki etkilerini araştırmayı amaçladık.

\section{GEREC VE YÖNTEM}

Çalışma grubu Wistar Albino sıçanlarla oluşturuldu. Grup 1, abdominal kompartman grubuydu. Anestezi altındaki s1çanların karnına basınç uygulandı. Gaz boşaltıldıktan 3 gün sonra sıçanlar sakrifiye edildi, karaciğer, bağırsak ve akciğer doku parçalarında oksidatif hasar parametresi olarak malonildialdehit (MDA) ve glutatyon (GSH) seviyeleri ile enflamatuvar parametre olarak miyeloperoksidaz (MPO) aktivitesi ölçüldü. Alınan kan örneklerinde serum alaninaminoasit transferaz (ALT) ve aspartat-aminoasit transferaz (AST) seviyeleri ölçüldü. Grup 2, abdominal kompartman ve glutamin uygulanan gruptu. Sıçanlara 1 hafta boyunca yüksek doz glutamin mide gavajı yolu ile verildi. Gavaj işlemi sonrası ilk gruptaki batın içi basınç uygulamas1 yapıldı, 3 gün daha glutamin verilen sıçanlar sakrifiye edildi, Grup 1'deki işlemlerin aynısı yapıldı. Grup 3 glutamin grubuydu. Grup 4 sham kontrol grubuydu.

\section{BULGULAR}

Abdominal kompartman yaratılan sıçanlarda MDA düzeyi ve MPO aktivitesi kontrol grubuna göre anlamlı oranda artmıştı. Glutamin ile MDA düzeyi ve MPO aktivitesi azaldı, GSH seviyesi artt1.

\section{SONUÇ}

Oksidatif hasar parametrelerine bakıldığında, glutaminin, reperfüzyon hasarını azaltıcı etkisinin antienflamatuvar ve antioksidan etkilerine bağlı olduğu düşünülmüştür.

Anahtar Sözcükler: Abdominal kompartman sendromu; antioksidan; glutamin; glutatyon; iskemi; malonildialdehit; miyeloperoksidaz; oksidatif stres; reperfüzyon.

\footnotetext{
Departments of ${ }^{1}$ General Surgery, ${ }^{2}$ Biochemistry, Istanbul University, Bagcilar Training and Research Hospital, Istanbul, Turkey.
}

İstanbul Üniversitesi İstanbul Tıp Fakültesi, ${ }^{1}$ Genel Cerrahi Anabilim Dalı, ${ }^{2}$ Biyokimya Anabilim Dalı, İstanbul; ${ }^{3}$ Bağcılar Eğitim ve Araştırma Hastanesi, Genel Cerrahi Kliniği, İstanbul. 
Intraabdominal pressure (IAP) may increase in a variety of conditions ranging from trauma to abdominal surgery, from laparoscopic surgery to acute pancreatitis. ${ }^{[1]}$ When IAP exceeds $15 \mathrm{mmHg}$, intraabdominal hypertension (IAH) ensues. IAH may be encountered in various clinical situations due to edema of the small intestinal wall following aggressive fluid replacement, extensive retroperitoneal bleeding, postoperative complications, acute renal failure, treatment-resistant massive ascites, serious pancreatitis, and retroperitoneal tumoral masses. ${ }^{[2-4]}$

Ischemia is defined as inadequacy or cessation of blood flow to a certain tissue or organ. ${ }^{[5]}$ The tissue becomes exposed to hypoxia and hypoxic tissue damage arises. Long-term ischemia threatens structural cell integrity, and even cell death ensues..$^{[5,6]}$ Reperfusion is re-establishment of blood flow to a certain tissue. ${ }^{[5,7]}$ When blood flow to a previously ischemic tissue is restored (reperfusion), tissue destruction is further exacerbated by free oxygen radicals released from polymorphonuclear leukocytes (PMNL) that migrate and reside in the tissue, and reperfusion-induced tissue damage occurs. ${ }^{[5,7-9]}$ A variety of cells struggle against the potential hazards of free oxygen radicals by releasing enzymatic and non-enzymatic antioxidants in order to limit radical injury. Glutathione (GSH) is one of the non-enzymatic antioxidant protectors. It is well known that glutamine, which exists in blood and body fluids in high concentrations, plays a critical role in GSH biosynthesis by providing glutamate to the glutathione system. ${ }^{[10-12]}$

In light of the above, considering the antioxidant effects of glutamine, we planned to investigate whether or not glutamine administration has favorable effects on serious oxidative damage that results from increased IAP. We intended to observe whether glutamine has an alleviating effect on ischemia-reperfusion injury that occurs during and following abdominal compartment syndrome (ACS) by assessing the inflammation and oxidative damage parameters obtained.

\section{MATERIALS AND METHODS}

The experimental part of the study was performed in Istanbul University, Institute of Experimental Medicine and Research, between August and October 2006. Biochemical examinations were performed in the Istanbul University Faculty of Medicine, Department of Biochemistry. Experiments were performed with permission of the Animal Ethics Committee of Istanbul University (Decision date and number: 20.09.2005 31.2005).

\section{Subjects and Experimental Protocol}

Thirty-two adult male Wistar Albino rats were used for the present study. The weight range was 200-250 grams (g) and all rats were kept in iron cages with a 12-hour day/night cycle and $22^{\circ} \mathrm{C}$ room temperature. The rats planned to undergo the IAP study were fasted the night before.

A 6 French $(F)$ orogastric feeding tube was inserted in subjects planned for glutamine administration and then glutamine suspension, which was prepared with distilled water, was administered through gastric gavage for 10 days at a dose of $1 \mathrm{ml}$ per day $(1 \mathrm{~g} / \mathrm{kg} /$ day $)$. In order to create an ACS model under ketamine anesthesia, abdomens of the rats were shaved and following application of an aseptic and antiseptic $10 \%$ povidone iodine solution, a 16-gauge sterile Angiocath was inserted intraperitoneally and $20 \mathrm{mmHg}$ pressure was applied for 2 hours (h) using $\mathrm{CO}_{2}$. Rats were sacrificed using high-dose ketamine.

Three samples each of liver, small intestine and lung tissue were taken from each subject. Tissues and lumens of small intestine samples were washed twice with PBS (phosphate-buffered saline) solution at $4{ }^{\circ} \mathrm{C}$ and immediately afterwards were placed into CryoTubes and stored in a deep freezer at $-80^{\circ} \mathrm{C}$ until the date of biochemical analyses. Blood samples taken from the heart apex when apical beat was present were put into yellow cap dry biochemistry tubes and centrifuged in 3000-3500 rpm for 15 minutes (min). Serum samples that were taken from each animal were put in three different Eppendorf tubes and stored in a deep freezer at $-80^{\circ} \mathrm{C}$ until the date of biochemical analyses. Malondialdehyde (MDA) and GSH levels as oxidative damage parameters and myeloperoxidase (MPO) levels as an inflammatory parameter were measured in tissue samples, whereas serum alanine aminotransferase (ALT) and aspartate aminotransferase (AST) levels were measured in blood samples (Table 1).

Subjects were divided into four groups as follows:

Group $1(\mathrm{n}=8)$, ACS model group: Using an Angiocath, $20 \mathrm{mmHg}$ constant pressure was applied for 2 $\mathrm{h}$ intraperitoneally to the rats, which were under anesthesia. The rats were sacrificed three days after emptying of the intraperitoneal gas, and tissue samples were taken from the liver, intestine and lung and blood sample from the heart apex.

Group $2(\mathrm{n}=8)$, ACS model and glutamine-administered group: Each rat was administered high-dose glutamine through gastric gavage for one week. Following a one-week lavage administration, intraperitoneal pressure application was performed as in Group 1. The rats were administered glutamine for three more days after emptying of the gas, were sacrificed, and then tissue and blood samples were taken as in Group 1.

Group $3(\mathrm{n}=8)$, glutamine group: Each rat was administered high-dose glutamine through gastric ga- 
vage for 10 days. At the end of 10 days, the anesthetized rats were sacrificed without pressure application and the same blood and tissue samples were taken.

Group 4 ( $\mathrm{n}=8)$, control group: Rats were only anesthetized without pressure application, were sacrificed, and the same tissue and blood samples were taken.

\section{Examinations of Tissue Samples}

The liver, intestine and lung samples were weighed. In order to detect MDA and GSH levels, their 10\% homogenates were prepared by homogenizing with cold $0.15 \mathrm{M} \mathrm{KCl}$ solution in a homogenizer.

\section{Measurement of Glutathione (GSH) Levels}

Measurement of GSH is based on the principal that Ellman's reagent (5,5'-dithiobis-2 nitrobenzoic acid) is reduced by free sulfhydryl groups (-SH) of tissue homogenate. 1 mole of 2 nitro 5 thiobenzoic acid (DTNB) occurs per 1 mole of SH group, and this gives absorbance in $412 \mathrm{~nm}$ in spectrophotometer.

GSH levels were computed using extinction quotient and standard. Results were stated as $\mathrm{GSH} / \mathrm{mg}$ protein.

\section{Measurement of Malondialdehyde (MDA) Levels}

MDA (which is one of the late products of lipid peroxidation) and TBA (thiobarbituric acid) complex is measured spectrophotometrically. $10 \%$ tissue homogenates were used for this method. Results were computed using extinction quotient and standard. MDA levels were stated as MDA/mg protein.

\section{Protein Detection}

The protein amount in tissue homogenates was detected using bicinchoninic acid assay. This method is based on the principal that copper-protein complex forms chelate with bicinchoninic acid and gives absorbance in $562 \mathrm{~nm}$.

\section{Detection of Myeloperoxidase (MPO) Activity}

This method is based on the principal that MPO activity containing homogenate reduces o-dianisidine dihydrochloride in the presence of $\mathrm{H}_{2} \mathrm{O}_{2}$, and this reduced product gives absorbance in $460 \mathrm{~nm}$. MPO activity was computed using o-dianisidine extinction quotient. Results were stated as U/g tissue.

\section{Examinations of Serum Samples}

ALT and AST activities were examined enzymatically in serum using Roche autoanalyzer.

\section{Statistical Analyses}

The results of biochemical data were stated as arithmetic average \pm standard error. Statistical assessment was performed using one way analysis of variance (ANOVA), and further analysis was performed with Tukey's test. Values of $p<0.05$ values were considered statistically significant.

\section{RESULTS}

\section{Biochemical Analyses}

\section{Serum AST and ALT Levels}

AST and ALT levels were found to be significantly higher in the ACS group (Group 1) compared to controls (Group 4). AST and ALT levels of the glutamineadministered and ACS model group (Group 2) were not significantly different from controls (Group 4), whereas these levels were significantly lower when compared to the ACS group (Group 1). There were no significant differences between the glutamine group (Group 3) and controls (Fig. 1).

\section{Oxidative Damage and Inflammation Parameters \\ MDA Level}

Lung: The MDA level was found to be significantly higher in the ACS group (Group 1) compared to controls (Group 4) $(\mathrm{p}<0.05)$. The MDA level of the glutamine-administered and ACS model group (Group 2) was not significantly different from controls (Group 4), whereas it was significantly lower when compared to the ACS group (Group 1) $(\mathrm{p}<0.05)$. There were no significant differences between the glutamine group (Group 3) and controls (Fig. 2).

Liver: The MDA level was found to be significantly higher in the ACS group (Group 1) compared to controls (Group 4) $(\mathrm{p}<0.05)$. The MDA level of the glutamine-administered and ACS model group (Group 2) was not significantly different from controls (Group 4), whereas it was significantly lower when compared to the ACS group (Group 1) $(\mathrm{p}<0.05)$. There were no significant differences between the glutamine group (Group 3) and controls (Fig. 2).

Small Intestine: The MDA level was found to be significantly higher in the ACS group (Group 1) com-

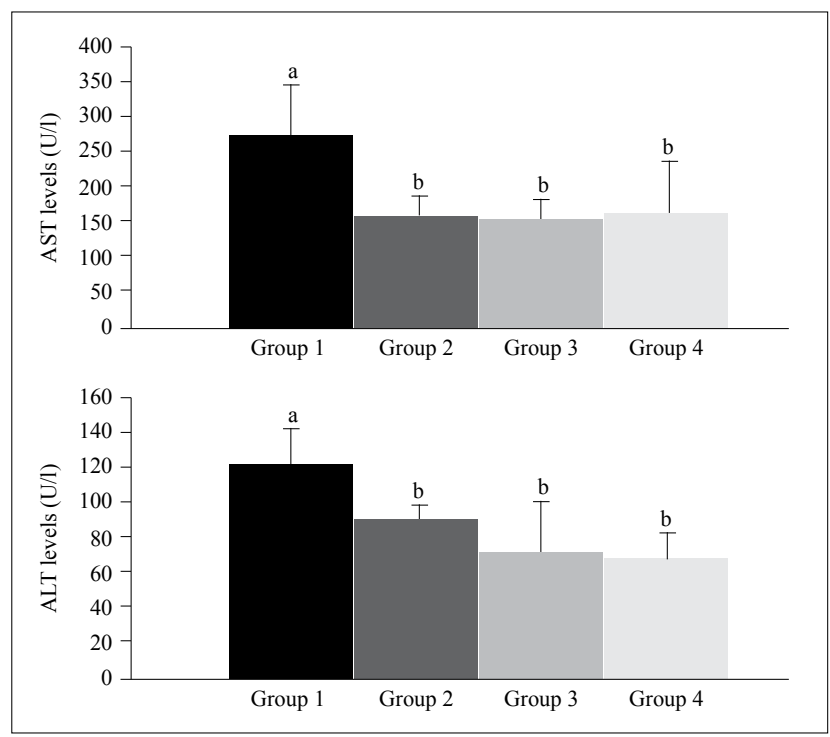

Fig. 1. Serum AST and ALT values (different letters show significance $(\mathrm{p}<0.05))$. 

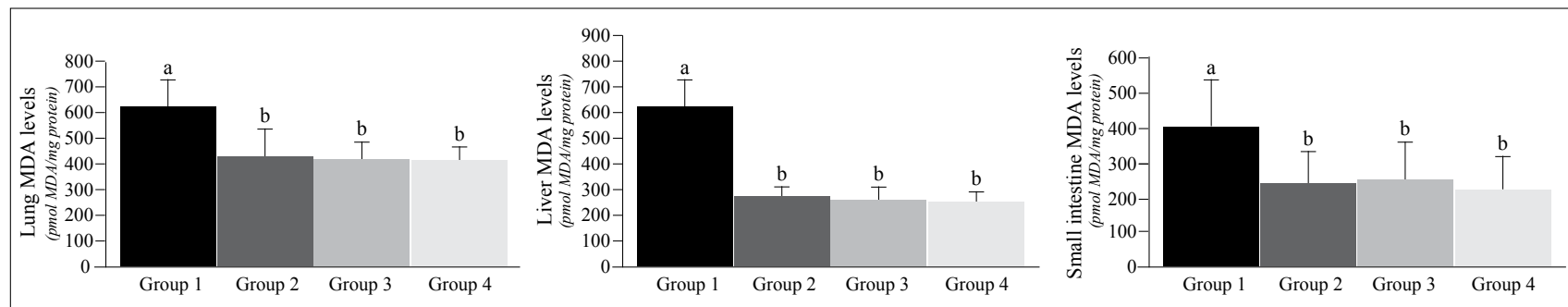

Fig. 2. Tissues MDA levels (different letters show significance $(p<0.05)$ ).
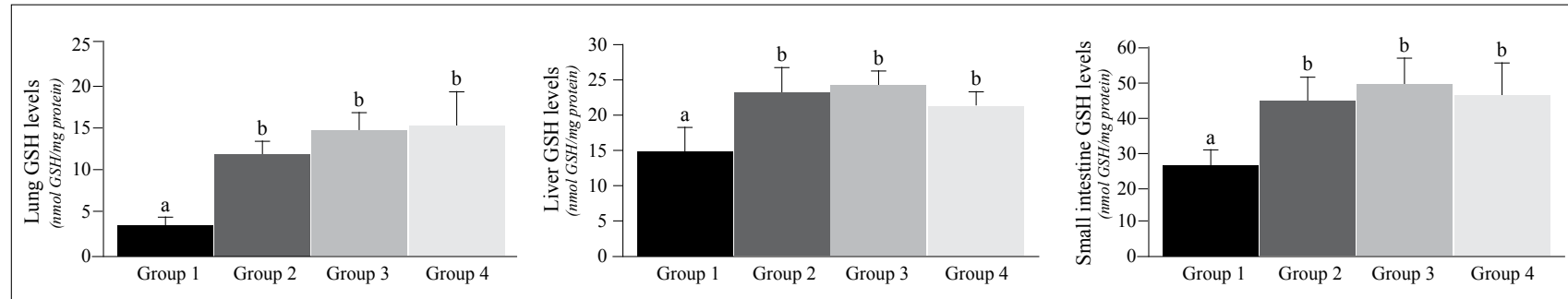

Fig. 3. Tissues GSH levels (different letters show significance $(\mathrm{p}<0.05))$.
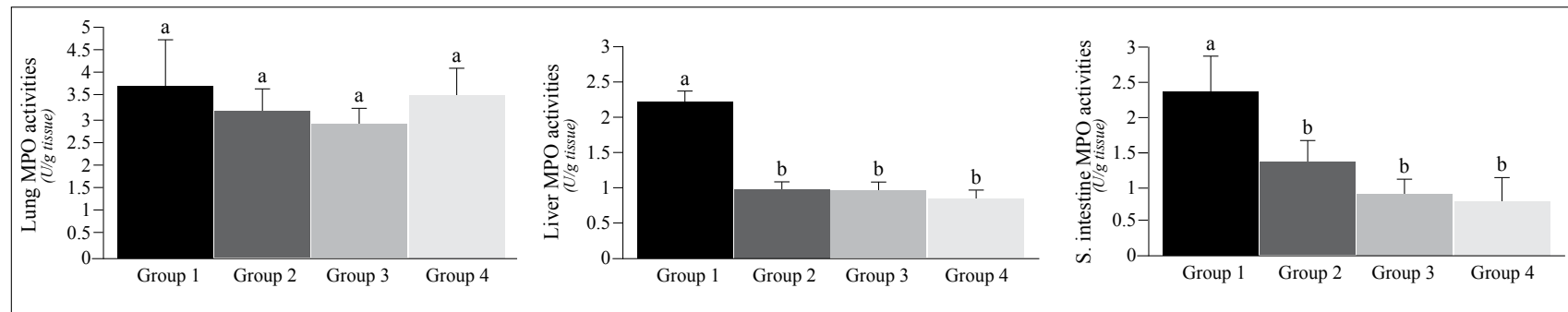

Fig. 4. Tissues MPO activity (different letters show significance $(\mathrm{p}<0.05)$ ).

pared to controls (Group 4) $(\mathrm{p}<0.05)$. The MDA level of the glutamine- administered and ACS model group (Group 2) was not significantly different from controls (Group 4), whereas it was significantly lower when compared to the ACS group (Group 1) $(\mathrm{p}<0.05)$. There were no significant differences between the glutamine group (Group 3) and controls (Fig. 2).

\section{GSH Level}

Lung: The GSH level was found to be significantly higher in the ACS group (Group 1) compared to controls (Group 4) $(\mathrm{p}<0.05)$. The GSH level of the glutamine-administered and ACS model group (Group 2) was not significantly different from controls (Group 4 ), whereas it was significantly lower when compared to the ACS group (Group 1) $(\mathrm{p}<0.05)$. There were no significant differences between the glutamine group (Group 3) and controls (Fig. 3).

Liver: The GSH level was found to be significantly higher in the ACS group (Group 1) compared to controls (Group 4) $(p<0.05)$. The GSH level of the glutamine-administered and ACS model group (Group 2) was not significantly different from controls (Group 4), whereas it was significantly lower when compared to the ACS group (Group 1) $(\mathrm{p}<0.05)$. There were no significant differences between the glutamine group (Group 3) and controls (Fig. 3).

Small Intestine: The GSH level was found to be significantly higher in the ACS group (Group 1) compared to controls (Group 4) $(p<0.05)$. The GSH level of the glutamine- administered and ACS model group (Group 2) was not significantly different from controls (Group 4), whereas it was significantly lower when compared to the ACS group (Group 1) $(\mathrm{p}<0.05)$. There were no significant differences between the glutamine group (Group 3) and controls (Fig. 3).

\section{MPO Activity}

Lung: No significant differences were found between groups (Fig. 4).

Liver: MPO activity was found to be significantly higher in the ACS group (Group 1) compared to controls (Group 4) $(\mathrm{p}<0.05)$. MPO activity in the glutamine-administered and ACS model group (Group 2) was not significantly different from controls (Group 4 ), whereas it was significantly lower when compared to the ACS group (Group 1) $(\mathrm{p}<0.05)$. There were no significant differences between the glutamine group (Group 3) and controls (Fig. 4). 
Table 1. Mean values and standard deviations of AST and ALT (U/L), tissue GSH (nmol GSH/mg protein) and MDA (pmol MDA/mg protein) levels and MPO activity (U/g tissue) data in subject groups

\begin{tabular}{lcc}
\hline Groups & AST levels & ALT levels \\
\hline Group 1 & $268.1 \pm 76$ & $118.8 \pm 21.4$ \\
Group 2 & $153.8 \pm 30.4$ & $88.7 \pm 7.2$ \\
Group 3 & $148.8 \pm 29.7$ & $70.6 \pm 28.4$ \\
Group 4 & $158.8 \pm 71.7$ & $67.8 \pm 15.7$ \\
\hline
\end{tabular}

\begin{tabular}{lccc} 
Groups & \multicolumn{3}{c}{ GSH levels } \\
\cline { 2 - 4 } & Lung & Liver & Small intestine \\
\hline Group 1 & $4.87 \pm 1.27$ & $15.32 \pm 3.83$ & $26.85 \pm 3.78$ \\
Group 2 & $12.35 \pm 2.64$ & $23.14 \pm 4.95$ & $44.33 \pm 14.5$ \\
Group 3 & $15.67 \pm 2.31$ & $24.4 \pm 2.32$ & $49.92 \pm 9.95$ \\
Group 4 & $15.58 \pm 4.7$ & $21.85 \pm 2.45$ & $46.39 \pm 9.69$ \\
\hline
\end{tabular}

\begin{tabular}{lccc} 
Groups & \multicolumn{3}{c}{ MDA levels } \\
\cline { 2 - 4 } & Lung & Liver & Small intestine \\
\hline Group 1 & $624.8 \pm 101.3$ & $612.9 \pm 157.6$ & $409.8 \pm 150$ \\
Group 2 & $430.2 \pm 115.7$ & $301.9 \pm 53.7$ & $246.7 \pm 103.8$ \\
Group 3 & $437.8 \pm 73.9$ & $288.9 \pm 47.3$ & $240.9 \pm 97.5$ \\
Group 4 & $421.4 \pm 85$ & $281 \pm 49$ & $225.9 \pm 113.2$ \\
\hline
\end{tabular}

\begin{tabular}{lccc} 
& \multicolumn{3}{c}{ MPO activities } \\
\cline { 2 - 4 } & Lung & Liver & Small intestine \\
\hline Group 1 & $3.76 \pm 0.23$ & $2.35 \pm 0.6$ & $2.37 \pm 0.56$ \\
Group 2 & $3.11 \pm 1.1$ & $1.04 \pm 0.12$ & $1.32 \pm 0.32$ \\
Group 3 & $2.99 \pm 0.54$ & $1.04 \pm 0.46$ & $0.92 \pm 0.21$ \\
Group 4 & $3.55 \pm 0.6$ & $0.95 \pm 0.23$ & $0.89 \pm 0.78$ \\
\hline
\end{tabular}

Small Intestine: MPO activity was found to be significantly higher in the ACS group (Group 1) compared to controls (Group 4) $(\mathrm{p}<0.05)$. MPO activity of the glutamine- administered and ACS model group (Group 2) was not significantly different from controls (Group 4), whereas it was significantly lower when compared to the ACS group (Group 1) $(\mathrm{p}<0.05)$. There were no significant differences between the glutamine group (Group 3) and controls (Fig. 4).

\section{DISCUSSION}

Abdominal compartment syndrome (ACS), which results from a sudden increase in IAP, is a frequent condition seen in clinical practice, especially in emergency surgery, trauma clinics and intensive care units, and it is sometimes fatal. ${ }^{[13-17]}$ Because laparoscopic interventions increase IAP, negative effects of IAP elevation due to minimally invasive abdominal surgical interventions sometimes occur. Although MendozaSagaon et al. ${ }^{[18]}$ reported that laparoscopic cholecystectomy does not significantly increase stress response in pigs compared to open cholecystectomy, Akbulut et al. ${ }^{[19]}$ reported in an experimental study that oxidative damage occurs due to pneumoperitoneum, which was produced in order to imitate laparoscopic donor nephrectomy in rat kidneys, and this damage increases with pneumoperitoneum duration.

Oxidative damage created by free radicals emerging from increased IAP is one of the important physiopathologic components of ACS at the cellular base. ${ }^{[13]}$ Free radicals may disrupt DNA transcription and replication by generating breaks in DNA helixes and may cause cell death in subsequent mitosis. ${ }^{[6,7,9]}$ It is known that free radicals cause damage by increasing the synthesis of proinflammatory mediators like cytokines, and this oxidative damage could be demonstrated using the parameters of GSH and MDA. Serum ALT levels also increase as a result of hepatic dysfunction due to IAP increase. A continued increase in AST and ALT levels in the blood during and after the decompression period indicates tissue damage due to reperfusion. In our study, MDA levels, which indicated lipid peroxidation, were significantly higher, and GSH levels, which indicated antioxidant capacity, were significantly lower in subjects that underwent ACS model generation when compared to controls. It was observed that AST and ALT levels were high in the serum samples of the subjects in which the ACS model was generated.

Reperfusion causes emergence of many reactive oxygen species and related disruption of cellular function to varying degrees. Ischemia-reperfusion creates an acute inflammatory response proceeding with neutrophil activation. Proteases and cytotoxic proteins like MPO and reactive oxygen species are released from neutrophils to the extracellular fluid. It was shown in various studies that nuclear factor (NF) $\mathrm{\kappa B}$ activation ensued due to release of free oxygen radicals. As a result of this activation, synthesis of mediators including interleukin (IL)-1, IL-6, IL-8, IL-12, tumor necrosis factor (TNF)- $\alpha$, inducible nitric oxide synthase (iNOS), cyclooxygenase (COX)-2, intercellular adhesion molecule (ICAM), and vascular adhesion molecule (VCAM) is stimulated and an inflammatory response occurs. Therefore, the amount of proinflammatory molecules is regulated by NF- $\kappa \mathrm{B} \cdot{ }^{[20-22]}$

Organ failure subsequent to reperfusion proceeds with decreased microvascular permeability, edema, disordered vasoregulation, infiltration of inflammatory cells, parenchymal cell damage, and necrosis. ${ }^{[23]}$ If synthesis of oxidants, cytokines and various mediators emerging in pathological settings during which tissue damage occurs cannot be prevented, sepsis and multiorgan failure may occur. If the effect of the blood-intestine barrier is considered in sepsis, the importance of prevention of oxidative damage and bacterial translocation can be recognized. ${ }^{[24,25]}$ 
As a result of ACS, cytokine activation occurs and organ damage is seen. ${ }^{[23]}$ It is known that activity of the MPO enzyme, which is released from neutrophils, increases in the ischemic period seen during IAP increase. However, MPO activity is greater in the reperfusion period following decompression than in the ischemia period. ${ }^{[26]}$ In our study, it was observed that as an oxidative stress parameter, MPO activity increased in tissue samples of rats in which the ACS model was generated. However, MPO activity was significantly decreased in the ACS model + glutamine administration group. No significant difference was found between groups when MPO activities in lung tissue samples taken from the rats were considered alone.

GSH is the most important defensive mechanism preventing development of oxidative damage, and it thus protects homeostasis at the cellular base. ${ }^{[27-29]}$ Previous studies showed that tissue GSH levels and activities of GSH peroxidase and GSH reductase enzymes, which are critical components of the GSH redox cycle, consequently decrease when the metabolism becomes exposed to oxidative stress. ${ }^{[30,31]}$ In our study, compatible with the literature, it was observed that tissue GSH levels decreased following the ischemia-reperfusion period in animal subjects in which the ACS model was generated, and this decrement could significantly be precluded in the group supplemented with glutamine.

Glutamine is a non-essential amino acid, the importance of which has been recognized in recent years. It acts as an energy source for rapidly regenerating cells like enterocytes, colonocytes and lymphocytes. It also has metabolic effects including protein synthesis and regulation of acid base balance, anabolic and trophic effects, gluconeogenesis, nucleic acid synthesis, GSH synthesis, and immunologic cell regulation. Moreover, studies have shown that glutamine regulates chemotherapy-related alterations in intestinal absorption and intestinal permeability and has favorable effects on radiation-related tissue damage. ${ }^{[32,33]}$

Although glutamine is synthesized and stored in the organism, its consumption increases rapidly in catabolic conditions like major surgery, sepsis, trauma, and inflammation. ${ }^{[32-38]}$ Glutamine, together with alanine and arginine, is one of a few amino acids the level of which decreases as a result of increased consumption due to a variety of inner and outer processes creating stress in metabolism and compromising homeostasis. Although it could not be statistically confirmed, it was reported that favorable results were obtained with glutamine-supplemented parenteral nutrition in intensive care patients who could not be provided nutrition via the enteral route for a long period. ${ }^{[12,36-40]}$ In experimental models of sepsis, burn, radiation enteritis, ischemia-reperfusion, total parenteral nutrition, and starvation, it was demonstrated that glutamine administration decreased oxidative damage and bacterial translocation and provided protection for the mucosal barrier with increasing secreted IgA levels..$^{[20,34-38,41]}$ It was found that glutamine reabsorption was affected, and transport of glutamine from the intestinal lumen and glutaminase activity increased in sepsis and trauma and in conditions where levels of stress hormones increased. ${ }^{[32,34,36,42,43]}$

Glutamine is also responsible for NADPH and ATP production. Increased utilization of cellular glutamine delays and also prevents neutrophil apoptosis. Chang et al. ${ }^{[44]}$ investigated the antiapoptotic effect of glutamine in one study about the effects of glutamine on $\mathrm{T}$ cells. It was found that glutamine not only regulated intracellular oxidative balance but also precluded especially $\mathrm{T}$ cell apoptosis. An increase in bcl-2 gene expression is thought to be the most important step of apoptosis preventing the effect of glutamine in the period following its entry into the cell. ${ }^{[45,46]}$ Moreover, it is emphasized that glutamine administration to burn patients increases the bacterial killing ability of neutrophils and regulates release of free radicals. ${ }^{[37,47]}$

Various studies demonstrated that ischemia reperfusion in organs is related with lipid peroxidation. The autocatalytic mechanism triggered by lipid peroxidation causes oxidative damage in the cell membrane. Toxic and reactive metabolites, which emerge as a result of this process, cause cell death. ${ }^{[48,49]}$ Because MDA is one of the latest products of the lipid peroxidation process, it is a reliable parameter for assessing the degree of peroxidation and thus oxidative damage. There are studies in the literature demonstrating a $40 \%$ to $100 \%$ increase in MDA levels from baseline following ischemia reperfusion. ${ }^{[48-50]}$

In models of ischemia-reperfusion, it was established that iNOS gene expression decreased in subjects fed a glutamine-supplemented diet. ${ }^{[1]}$ It is also known that glutamine acts as an important step in GSH synthesis. On the other hand, NF- $\kappa B$ activation is closely associated with intracellular redox balance and the GSH/GSSG ratio. Glutamine administration increased intracellular GSH and decreased NF- $\kappa B$ release. This decrement in NF- $\kappa \mathrm{B}$ expression precludes dependent release of cytokines. ${ }^{[20,52-54]}$ In our study, it was established that there was a significant decrease in oxidative damage parameters in glutamine- administered rats with ACS compared to those in whom ACS was generated without glutamine administration.

Various substances were tested in order to prevent and treat oxidative damage in clinical and experimental settings. Administration of protective substances including probiotics, radical scavengers, selenium, vitamin E, ascorbic acid, glutamine, taurine, betaine, 
melatonin, alanine, curcumin, anti IL-10 receptor antibodies, and anti IL- 6 receptor antibodies was found to decrease oxidative damage. Kaçmaz et al. ${ }^{[50]}$ reported that octreotide application significantly decreased reperfusion-related oxidative damage in models of acute abdominal hypertension-generated rats. Protective effects of these agents are attributed to their alleviating effects on synthesis of free oxygen, nitrites and nitrate radicals. ${ }^{[20,24,34,35,55,56]}$

In our study, IAP increase was found to increase the inflammatory response and reperfusion-related oxidative damage. Oxidative damage was established with an increase in MDA levels and decrease in GSH levels in the lung, liver and small intestine tissues; inflammatory response was established with an increase in MPO activity in the liver and small intestine tissues. Glutamine was found effective when administered in order to alleviate the oxidative damage and inflammation developed in these tissues.

This study demonstrates that the favorable and protective effects of glutamine, which is also known as an antiapoptotic amino acid, on oxidative damage secondary to ACS-generated ischemia reperfusion are due to its antioxidant and antiinflammatory properties.

As a result, it was observed that glutamine diminished oxidative stress-related damage in IAP increase and ACS. This effect can be explained by glutamine's antioxidant and antiinflammatory features. Glutamine can be applied as a therapeutic agent in confining reperfusion damage elicited by visceral ischemia due to ACS, which occurs during and/or following traumatic and surgical procedures and as a result of IAP increase generated by laparoscopic surgical techniques, which are used extensively today. Before and after clinical settings that proceed with IAP increase, glutamine should be added to nutritional supplements of patients in which ACS development is possible.

\section{REFERENCES}

1. Cullen DJ, Coyle JP, Teplick R, Long MC. Cardiovascular, pulmonary, and renal effects of massively increased intraabdominal pressure in critically ill patients. Crit Care Med 1989; 17:118-21.

2. Chen RJ, Fang JF, Chen MF. Intra-abdominal pressure monitoring as a guideline in the nonoperative management of blunt hepatic trauma. J Trauma 2001;51:44-50.

3. Asensio JA, Ceballos J, Forno W. Intra-abdominal pressure monitoring. In: WC Shoemaker, GC Velhamos, D Demetriades, editors. Procedures and monitoring for the critically ill. Philadelphia: W.B. Saunders; 2002. p. 99-103.

4. Ivatury RR, Diebel L, Porter JM, Simon RJ. Intra-abdominal hypertension and the abdominal compartment syndrome. Surg Clin North Am 1997;77:783-800.

5. Kumar V, Cotran RS, Robbins SL. Basic pathology. Philadelphia: W.B. Saunders; 1992. p. 4-11.

6. Clarkson AN, Sutherland BA, Appleton I. The biology and pathology of hypoxia-ischemia: an update. Arch Immunol
Ther Exp (Warsz) 2005;53:213-25.

7. de Groot H, Rauen U. Ischemia-reperfusion injury: processes in pathogenetic networks: a review. Transplant Proc 2007;39:481-4.

8. Ley K, Reutershan J. Leucocyte-endothelial interactions in health and disease. Handb Exp Pharmacol 2006:97-133.

9. Gutteridge JM, Halliwell B. Free radicals and antioxidants in the year 2000. A historical look to the future. Ann N Y Acad Sci 2000;899:136-47.

10. Rodwell VW. Metabolism of proteins and aminoacids. In: Murray RK, Granner DK, Mayes PA, Rodwell VW, editors. Harper's biochemistry. Appleton\&Lange; 1990. p. 333-412.

11. Tapiero H, Mathé G, Couvreur P, Tew KD. II. Glutamine and glutamate. Biomed Pharmacother. 2002;56:446-57.

12. Young VR, Ajami AM. Glutamine: the emperor or his clothes? J Nutr 2001;131:2449S-87S.

13. Guloglu R, Berber E, Taviloglu K, Gunay K, Ertekin C. Clinical importance of intraabdomainal pressure in the sugical intensive care. Eur J Emerg Surg Int Care 1997;20:191-4.

14. Saggi BH, Sugerman HJ, Ivatury RR, Bloomfield GL. Abdominal compartment syndrome. J Trauma 1998;45:597-609.

15. Van Hee R. An abdominal challenge: the compartment syndrome. G Chir 2007;28:413-8.

16. Eddy V, Nunn C, Morris JA Jr. Abdominal compartment syndrome. The Nashville experience. Surg Clin North Am 1997;77:801-12.

17. Schein M, Wittmann DH, Aprahamian CC, Condon RE. The abdominal compartment syndrome: the physiological and clinical consequences of elevated intra-abdominal pressure. J Am Coll Surg 1995;180:745-53.

18. Mendoza-Sagaon M, Hanly EJ, Talamini MA, Kutka MF, Gitzelmann CA, Herreman-Suquet K, et al. Comparison of the stress response after laparoscopic and open cholecystectomy. Surg Endosc 2000;14:1136-41.

19. Akbulut G, Polat C, Aktepe F, Yilmaz S, Kahraman A, Serteser $M$, et al. The oxidative effect of prolonged $\mathrm{CO} 2$ pneumoperitoneum on renal tissue of rats. Surg Endosc 2004;18:1384-8.

20. Huang Y, Li N, Liboni K, Neu J. Glutamine decreases lipopolysaccharide-induced IL-8 production in Caco-2 cells through a non-NF-kappaB p50 mechanism. Cytokine 2003;22:77-83.

21. Jobin C, Sartor RB. The I kappa B/NF-kappa B system: a key determinant of mucosalinflammation and protection. Am J Physiol Cell Physiol 2000;278:451-62.

22. Schmid RM, Adler G. NF-kappaB/rel/IkappaB: implications in gastrointestinal diseases. Gastroenterology. 2000;118:1208-28.

23. Oda J, Ivatury RR, Blocher CR, Malhotra AJ, Sugerman HJ. Amplified cytokine response and lung injury by sequential hemorrhagic shock and abdominal compartment syndrome in a laboratory model of ischemia-reperfusion. J Trauma 2002;52:625-32.

24. Neu J, Li N. Pathophysiology of glutamine and glutamate metabolism in premature infants. Curr Opin Clin Nutr Metab Care 2007;10:75-9.

25.Ziegler TR, Bazargan N, Leader LM, Martindale RG. Glutamine and the gastrointestinal tract. Curr Opin Clin Nutr Metab Care 2000;3:355-62.

26. Laight DW, Lad N, Woodward B, Waterfall JF. Assessment of myeloperoxidase activity in renal tissue after ischemia/reperfusion. Eur J Pharmacol 1994;292:81-8.

27. Roth E, Oehler R, Manhart N, Exner R, Wessner B, Strasser 
E, et al. Regulative potential of glutamine--relation to glutathione metabolism. Nutrition 2002;18:217-21.

28. Valencia E, Hardy G. Practicalities of glutathione supplementation in nutritional support. Curr Opin Clin Nutr Metab Care 2002;5:321-6.

29. Fläring UB, Rooyackers OE, Wernerman J, Hammarqvist F. Glutamine attenuates post-traumatic glutathione depletion in human muscle. Clin Sci (Lond) 2003;104:275-82.

30. Reiter RJ, Tan DX, Osuna C, Gitto E. Actions of melatonin in the reduction of oxidative stress. A review. J Biomed Sci. 2000;7:444-58.

31. Reiter RJ, Tan DX, Manchester LC, Qi W. Biochemical reactivity of melatonin with reactive oxygen and nitrogen species: a review of the evidence. Cell Biochem Biophys 2001;34:237-56.

32. Erbil Y, Oztezcan S, Giriş M, Barbaros U, Olgaç V, Bilge $\mathrm{H}$, et al. The effect of glutamine on radiation-induced organ damage. Life Sci 2005;78:376-82.

33. Daniele B, Perrone F, Gallo C, Pignata S, De Martino S, De Vivo R, et al. Oral glutamine in the prevention of fluorouracil induced intestinal toxicity: a double blind, placebo controlled, randomised trial. Gut 2001;48:28-33.

34. Labow BI, Souba WW. Glutamine. World J Surg 2000;24:1503-13.

35. Reeds PJ, Burrin DG. Glutamine and the bowel. J Nutr 2001;131:2505-24.

36. Karinch AM, Pan M, Lin CM, Strange R, Souba WW. Glutamine metabolism in sepsis and infection. J Nutr 2001;131:2535-51.

37.Peng X, Yan H, You Z, Wang P, Wang S. Effects of enteral supplementation with glutamine granules on intestinal mucosal barrier function in severe burned patients. Burns 2004;30:135-9.

38. Boelens PG, Houdijk AP, Fonk JC, Puyana JC, Haarman HJ, von Blomberg-van der Flier ME, et al. Glutamine-enriched enteral nutrition increases in vitro interferon-gamma production but does not influence the in vivo specific antibody response to KLH after severe trauma. A prospective, double blind, randomized clinical study. Clin Nutr 2004;23:391-400.

39. García-de-Lorenzo A, Zarazaga A, García-Luna PP, Gonzalez-Huix F, López-Martínez J, Miján A, et al. Clinical evidence for enteral nutritional support with glutamine: a systematic review. Nutrition 2003;19:805-11.

40. Bolotin G, Raman J, Williams U, Bacha E, Kocherginsky M, Jeevanandam V. Glutamine improves myocardial function following ischemia-reperfusion injury. Asian Cardiovasc Thorac Ann 2007; 15:463-7.

41. Hulsewé KW, van Acker BA, Hameeteman W, van der Hulst RR, Vainas T, Arends JW, et al. Does glutamine-enriched parenteral nutrition really affect intestinal morphology and gut permeability? Clin Nutr 2004;23:1217-25.

42. Ikeda S, Zarzaur BL, Johnson CD, Fukatsu K, Kudsk KA.
Total parenteral nutrition supplementation with glutamine improves survival after gut ischemia/reperfusion. JPEN J Parenter Enteral Nutr 2002;26:169-73.

43. Yeh SL, Lai YN, Shang HF, Lin MT, Chen WJ. Effects of glutamine supplementation on innate immune response in rats with gut-derived sepsis. Br J Nutr 2004;91:423-9.

44. Chang WK, Yang KD, Chuang H, Jan JT, Shaio MF. Glutamine protects activated human $\mathrm{T}$ cells from apoptosis by up-regulating glutathione and Bcl-2 levels. Clin Immunol 2002;104:151-60.

45. Pithon-Curi TC, Schumacher RI, Freitas JJ, Lagranha C, Newsholme P, Palanch AC, et al. Glutamine delays spontaneous apoptosis in neutrophils. Am J Physiol Cell Physiol 2003;284:1355-61.

46. Ran Q, Liang H, Gu M, Qi W, Walter CA, Roberts LJ 2nd, et al. Transgenic mice overexpressing glutathione peroxidase 4 are protected against oxidative stress-induced apoptosis. J Biol Chem 2004;279:55137-46.

47. Kudsk KA. Current aspects of mucosal immunology and its influence by nutrition. Am J Surg 2002;183:390-8.

48. Omar R, Nomikos I, Piccorelli G, Savino J, Agarwal N. Prevention of postischaemic lipid peroxidation and liver cell injury by iron chelation. Gut 1989;30:510-4.

49. Sumimoto K, Oku J, Dohi K, Kawasaki T. Lipid peroxidation in transplanted rat liver. Transplant Proc 1990;22:2023-4.

50. Kaçmaz A, Polat A, User Y, Tilki M, Ozkan S, Sener G. Octreotide improves reperfusion-induced oxidative injury in acute abdominal hypertension in rats. J Gastrointest Surg 2004;8:113-9.

51. Wasa M, Soh H, Shimizu Y, Fukuzawa M. Glutamine stimulates amino acid transport during ischemia-reperfusion in human intestinal epithelial cells. J Surg Res 2005;123:75-81.

52. Melis GC, ter Wengel N, Boelens PG, van Leeuwen PA. Glutamine: recent developments in research on the clinical significance of glutamine. Curr Opin Clin Nutr Metab Care 2004;7:59-70.

53. Bouteloup-Demange C, Claeyssens S, Maillot C, Lavoinne A, Lerebours E, Dechelotte P. Effects of enteral glutamine on gut mucosal protein synthesis in healthy humans receiving glucocorticoids. Am J Physiol Gastrointest Liver Physiol 2000;278:677-81.

54. Wischmeyer PE, Kahana M, Wolfson R, Ren H, Musch MM, Chang EB. Glutamine reduces cytokine release, organ damage, and mortality in a rat model of endotoxemia. Shock 2001;16:398-402.

55. McCauley R, Kong SE, Heel K, Hall JC. The role of glutaminase in the small intestine. Int $\mathrm{J}$ Biochem Cell Biol 1999;31:405-13.

56. Erman F, Balkan J, Cevikbaş U, Koçak-Toker N, Uysal M. Betaine or taurine administration prevents fibrosis and lipid peroxidation induced by rat liver by ethanol plus carbon tetrachloride intoxication. Amino Acids 2004;27:199-205. 